\title{
The Determinants of Employee's Performance: A Literature Review
}

\author{
Mohand Tuffaha ${ }^{1}$ \\ ${ }^{1}$ Department of Business Organization, Universitat Politècnica de València, Spain \\ Correspondence: Mohand Tuffaha, Department of Business Organization, Universitat Politècnica de València, \\ Spain.
}

Received: August 12, 2020; Accepted: August 22, 2020; Published: August 23, 2020

\begin{abstract}
This piece of research highlights a contextual understanding of employee performance's concept by identifying factors affecting employee performance in the organization. This achieved through analyzing literature in ISI (Web of Knowledge) from 2015 until 2019, after that determine factors influencing employee performance. The definition of employee performance is given, furthermore, the description of each factor which has an influence on employee performance. The result indicates that knowledge management, information and communication technology, employee's empowerment, innovation and creativity and organization culture have a significant impact on employee performance. On the other hand, the correlation between these factors has a vital role in maintaining employee's performance and attitude.
\end{abstract}

Keywords: performance, knowledge management, information and communication technology, empowerment, innovation and creativity, productivity

\section{Introduction}

Companies and organizations should focus on building employees positive performance, through providing employees with a group of tools and skills to meet out new realities and challenges (Batarlienè, Čižiūniené, Vaičiūte, Šapalaitè, \& Jarašūnienè, 2017). Globalization, new market demands, innovation and smart economy are considering a challenge, as well as, drivers for companies to maintain and improve employee performance (Cooper \& Ezzamel, 2013). Dealing with quick changes in technologies, stakeholders requirements and market demands are depending on reducing the gap within employees attitude as underpinning factor on achieving smart goals of the organization (Shah, Irani, \& Sharif, 2017).

Researchers have defined employee performance as well as highlighted parameters affecting employee performance as in the following. Anitha (2013) reports that the performance of an individual or an organization depends strongly on all organizational activities, policies, practices, knowledge management practices and employee engagement. These elements are vital determinants fostering high levels of employee performance. While Islami, Mulolli and Mustafa (2018) recognize managing performance as a planned process of which the key elements are agreement, measurement, support, feedback and positive reinforcement, which shaped outcomes in terms of performance expectation. Also, Bataineh (2017) highlight Employee's performance as a combination of efficiency and effectiveness of the employee's daily tasks to meet the expectations of the stakeholders. Isaac, Abdullah, Ramayah and Mutahar (2017) show that employees highly agree that implementing the internet in their job helped them in improving task process, education acquisition and the quality of their communication which lead to improving individual performance as well as organization. On the other hand, Pawirosumarto, Sarjana and Gunawan (2017) tide between employee performance and work environment that contains physical and nonphysical factors around employees which have a positive and significant effect on improving employee performance. While Smith and Bititc (2017) emphasis on improving performance measurement systems and performance management practices as factors of work's environment which enhance employee's engagement levels. Also, Mensah (2018) support their ideas when considered talent management as a critical success factor within companies which become the most core managerial value in our highly dynamic and uncertain market environment of the twenty-first-century era.

Based on these observations, this paper aims to enhance the understood of employee performance and the factors affecting it. Author proposing a conceptual model, consisting of five factors which are knowledge management, information and communication technology, employee's empowerment, innovation and creativity and organization culture (de Menezes \& Escrig, 2019) (see Figure 1). Furthermore, this model will identify the correlation between these factors and their impacting on employee performance. 


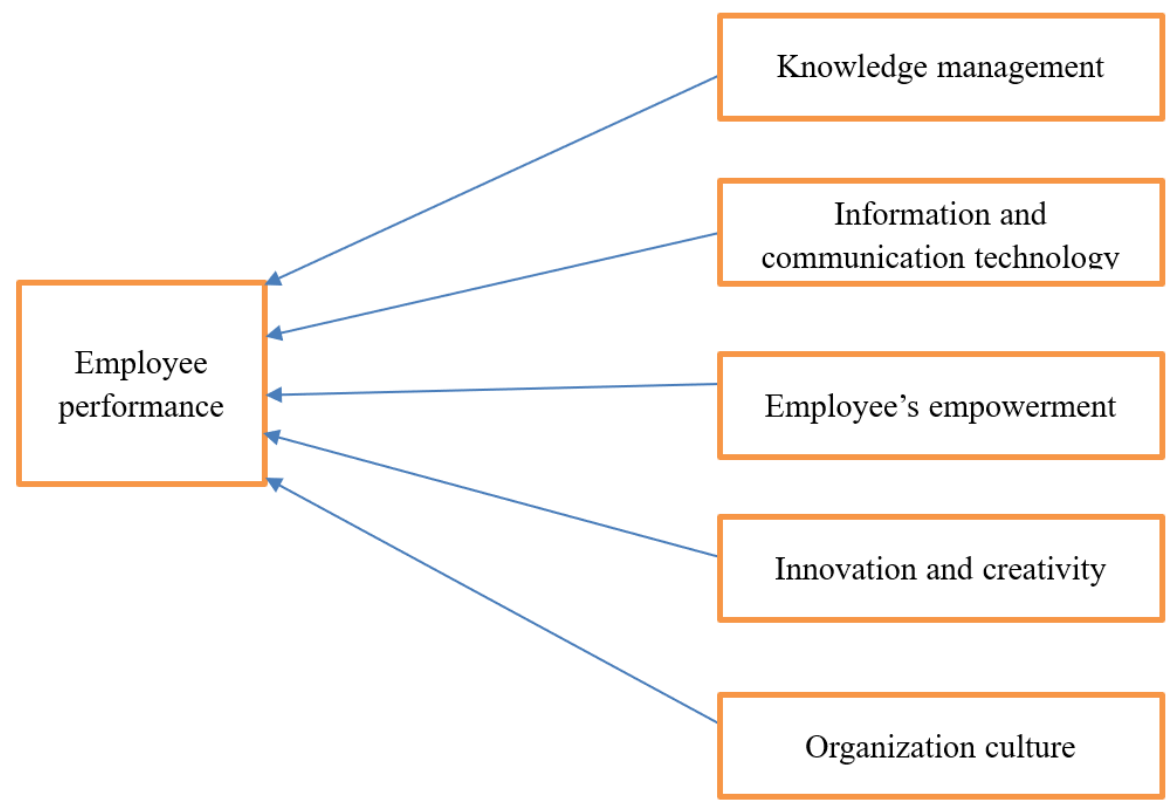

Figure 1. Factors affecting employee performance

\section{Methodology}

A systematic literature review aims to present a fair evaluation of a research topic by using a reliable, efficient and trustable approach (Kitchenham \& Charters, 2007). The author analyzed journals in ISI (Web of Knowledge) between 2015 and 2019. While selected articles are corralling with keywords of employee performance, knowledge management, information and communication, empowerment, innovation, creativity and organization culture. The correlation among the variables is based on a meta-analysis. Furthermore, the Boolean logic (i.e. AND or OR) was used to express relations between search terms and extract relevant articles.

In our case, the author used the distinct stages proposed by Kitchenham \& Charters(2007): (1) formulate the research questions and the search strategy, (2) filtering and extracting data based on inclusion and exclusion criteria, and (3) synthesizing the findings.

Research questions which are formulating literature review are: 1) what are factors affecting on employee performance? 2) Are there is a correlation between these factors? The result of these questions as the following

\subsection{Knowledge Management and Employee Performance}

Knowledge management has gained a huge of attention during the past few decades, as researchers have recognized the importance of managing knowledge in a knowledge-based economy (Ali, selvam, Paris, \& Gunasekaran, 2019).

Scholars defined knowledge Management as a concept that depends on collecting, auditing and sharing information within the organization's stakeholders (employees, customers and partners). While Susanty, Yuningsih, \& Anggadwita (2019) claim that knowledge management is a learning process that involves exploration, exploitation and share of knowledge supported by optimum technology and cultural environment. Gunjal (2019), emphases in his definition the importance of sharing information and data within the organization to enhance the capability of running a business efficiently and effectively. Promoting integration and collaboration approach in the overall organization department, lead to creating the enterprise's knowledge assets. These assets could intend to develop knowledge management systems that working on providing enterprises with machines and tools to restructure and manage knowledge. Depend on technological and social components across overall departments of the organization which are well-known recently as "socio-technical systems" (Hwang, Lin, \& Shin, 2018). This system should identify components to enhance enterprises utilizes such as organizational learning and total quality management, which lead to creating sustainable competitive advantages (Gunjal, 2019).

The result of the investigation on the relationship between knowledge management and employee's performance has been positive in most literature. This positiveness appeared in how four phases of the knowledge management process which are: 1) knowledge creation, 2) knowledge capture and storage, 3) knowledge sharing and 4) knowledge applications. These four phases have vital correlation on three essential pillars of performance which 
are innovation, quality of service delivery and operational efficiency of services (Ahbabi, Singh, Balasubramanian, \& Gaur, 2019).

Organization performance can be explained in terms of organization performance elements, that consist of market reputation, employee satisfaction, customers loyalty and market share (Imran, Ilyas, Aslam, \& Fatima, 2018) The core of the previous combination depends on knowledge sharing that is considered an essential tool to achieve the desired expectation of knowledge management. It's strongly believed that organizations' survival and success depend on sharing skills, knowledge and experiences within employees and transform them into ideas of innovations (Soto-Acosta, Popa, \& Palacios-Marqués, 2016). In other words, helping employees in creating new knowledge and motivate them with learning abilities will promote the culture of creativity and innovation in the organization which influence on employees attitude, behavior, skills and performance (Jyoti \& Rani, 2017).

Knowledge management infrastructure is a critical element in the knowledge management process. This result appeared when examining the positive relation of knowledge management infrastructure (Organizational Culture, IT Infrastructure, and Organizational Structure) on knowledge Management Process, and how knowledge management process significantly related to employees performance (Aalmajali \& Al-lozi, 2019). Abualoush, Masa'deh, Bataineh \& Alrowwad( 2018) conclude that knowledge management infrastructure contains two main factors: technical infrastructure factor and social infrastructure factor. Where technical infrastructure includes information technology infrastructures (software), tools, and hardware, on another hand, social infrastructure includes organizational culture, organization command structure and human resources.

Another critical element in the knowledge management process is a performance management system that working on tracking the implementation of organizational strategic objectives by evaluating individual performance (Sales, 2019). Asiaei \& Bontis(2019) assumed that the effectiveness of the performance management system appears in identifying the position of the organization in the current market and forecast the strategies of future market demands. Furthermore, the performance management system working on finical indicators such as profits, revenue and cost, and non-financial indicators by using Balance scored card which secures competitive advantages in the knowledge-based economy.

\subsection{Information and Communication Technology and Employee Performance}

The wide diffusion of information and communication technology (ICT) has been strongly impacting on the organization dynamism. ICT facilitates abroad range of organization's activities related to production, marketing, customer loyalty and employee performance (Reichstein, 2019). Shehata \& Montash (2019) claim that ICT transformed the nature of products, markets, companies and the competition itself. ICT restructures many industries, enhance managing cost and created entirely new business models. In details, Giotopoulos, Kontolaimou, Korra, \& Tsakanikas (2017) report that integration between ICT and organization operations reflected directly on organization performance and employee's productivity, cost-saving, organization effectiveness and open new markets.

The influence of ICT showed during 1990 when comparing the productivity growth between Europe and USA and how American's companies gained competitive advantages by using ICT widely in various economic sectors (Melián-González \& Bulchand-Gidumal, 2017). These sectors are recently affected with the Internet of things (IoT), cloud computing (CC) and predictive analytics (PA) (Ardolino, et al., 2018) which are a new trend in ICT (Dahiya \& Mathew, 2018). Caputo, Cillo, Candelo \& Liu (2019) report that the spread out of social networks, virtual realities, electronic devices, 3D printers and artificial intelligence (AI) among organization departments could enhance the impact of ICT. For instance, Big Data can support the processing of business intelligence (BI) tools, while artificial intelligence can support productivity work achieving (Caputo, Cillo, Candelo, \& Liu, 2019).

Human Resource department is one of the departments that is affected dramatically with information and communication technology. it is widely recognized that HRM function is influenced by the improvement of IT by transforming the way firms collect, store, analysis, evaluate employees performance (Turulja \& Bajgoric, 2018) The strategic approach of integration between HR and information technology lead to developing E-HRM (Rahman, Mordi, \& Nwagbara, 2018). Ayesha \& Yadav(2019) explain E-HRM as a combination of computer programs, software tools, databases, and hardware to record, store and analyze data necessary for the Human Resource (HR) applications. Organization portal considered an interface of E-HRM, which consist of Employee Portals, Enterprise Intranet Portals, Corporate Portals and Business-to-Employee Portals. These portals are serving different purposes like knowledge access, e-learning, LMS, online employees communities, (Ali, selvam, Paris, \& Gunasekaran, 2019). 
Many scholars highlighted the advantages of E-HRM. For instance, Rahman, Mordi, \& Nwagbara (2018) claim that E-HRM works as an analytical tool to help the decision-makers in making the valuable and accurate decision that leads to improv HR functions and employee's performance. Obeidat (2016) mentioned three different ways E-HRM supported the productivity of an organization through providing employees with required information about performance improvement, rewards allocation and performance appraisal. Armstrong (2016) emphasis on the value of E-HRM as a pathway to conduct E-training, which is the most efficient online intervention program that enhances the knowledge and skills of employees without tiding them to fix physical place or ignoring their busy schedule. Furthermore, E-training has a role in reducing the cost of the instructor, booking avenue, hardcopy materials and employee's time.

E-HRM's achievement marks a significant milestone in the relationship between employee performance and ICT. Tabatabaei, Omran, Hashemi, \& Sedaghat (2017) emphasis on ICT as the main source for sustainable employee performance by facilitating knowledge exposure, skills gaining and shrining experiences which enhance the competitive advantages of the organization. Also, maintaining recruitment and selection, performance appraisal and workforce planning (Glaister, Karacay, Demirbag \& Tatoglu, 2018).

\subsection{Empowerment Approach and Employee Performance}

The literature explains the empowerment approach as a management concept that constructs on dimensions of intrinsic motivation, job design, participative decision making, social learning theory, and self-management (Alazzaz \& Whyte, 2015). Potnuru, Sahoo, \& Sharma (2019), associate these dimensions with the organization's knowledge sharing, rewards systems that could empower the employees to enhance organizational competitiveness and performance.

García-Juan, Escrig-Tena \& Roca-Puig(2019) identify two different perspectives to understand empowerment. The first one is the structural perspective which contains a set of practices and structures that enable to transfer power and authority from the top to the bottom of the organization. While the second one is the psychological perspective that concerns an employee's attitudes in reaction to managerial practices. Lewis, Brown \& Sutton (2019) have the same conclusion through categorized employee's empowerment in structural and psychological. Structural empowerment, empowered employees with both direction and boundaries for their decision making which reflects the extent to which organizational decision rights are decentralized. Where psychological empowerment reflects an individual employee's subjective experience for competence and self-determination within their organizational role.

Empowering employees is critical in today's competitive environment where organizations are facing the pressure of globalization, rapid market changes and new customers demand. These challenges required innovative and creative solutions that rely on empowering employees to meet these challenges. (Shah, Khattak, Zolin, \& Shah, 2019).

To enhance the level of empowerment in the organizations, managements should expand communication with employees to make sure that employees are aware of the organization's mission, vision, value and desired targets of each individual. Besides, management should emphasis on face to face communication and integration activities across hierarchical levels as an approach to ensure a clear understanding of organizational strategies (Baird, $\mathrm{Su}, \mathrm{\&}$ Munir, 2018). Empirical studies point out that management can promote empowerment by engaging employee in decision-making and participation in organization objectives (Nayak, Sahoo, \& Mohanty, 2018). Kundu, Kumar \& Gahlawat (2019) add four managerial behaviours to maintain empowerment, namely, enhancing the meaningfulness of work, fostering participation in decision making, expressing confidence in high performance and providing autonomy from bureaucratic constraints.

This part of the literature investigates the theoretical relationship between employee performance and employee's empowerment as a central factor affecting organization surviving. The positive side of this relation appeared when scholars highlighted empowerment as one of the modern mechanisms that can be used to develop employees performance and make full use of their capabilities, which have a positive effect on employee's motivation and innovation to achieve the organization's objectives (Aldaihani, 2019). Also, scholars associated employee empowerment to organization outcomes by enhancing work satisfaction, reduce job-related strain and minimize employee turnover (Lewis, Brown, \& Sutton, 2019).

\subsection{Innovation, Creativity and Employee Performance}

Many organizations recently fighting to survive in rapid economic changes by developing and understanding the factors that promote the culture of innovation and creativity within employees. Therefore, many scholars have the conclusion that innovation and creativity are crucial in daily tasks and assignments. In this part of the study, we 
particularly looking upon the relationship between employee performance and innovation and creativity and the ways to implement strategies that support innovation and creativity in the organization.

Many scholars have been discussed innovation and creativity and highlighted the critical role of innovation and creativity in future organization success. Most researches have the almost same framework of explanation these terms. They identified creativity as a stage of process refers to idea generation, and innovation refers to the subsequent stage of implementing ideas toward better procedures, practices, or products (Olsson, Paredes, Johansson, Roese, \& Ritzén, 2019). Creativity as the development of new and useful solutions for challenging that is facing an organization, where innovation refers to the implementation or application of new and useful thoughts in the workplace (Khalili, 2018). Creativity is the generation of novel and useful ideas or solution while innovation is the actual implementation and execution of creative ideas (Kremer, Villamor, \& Aguinis, 2019). Creative workplace concerns the cognitive and behavioral processes applied when attempting to generate novel ideas. Innovate workplace concerns the processes applied when attempting to implement new ideas. (Hughes, Lee, Tian, Newman, \& Legood, 2018).

The question appears which one is coming first, innovation or creativity. According to Khalili (2018), creativity is a fundamental step in innovation. Kremer, Villamor, \& Aguinis (2019) agree with Khalili when they concerned the existing of innovation depending on creativity. The same scenario occurs with Wang, Cheng, Chen, \& Leung (2019) when they explained creativity and innovation as two closely related and overlapped concepts starting with the creativity and ending with innovation.

Promoting innovation within the organization passing through several processes, starting with the decision to innovate by budgeting investment. Then commercialization of original ideas, after that prepare an adequate work environment that motivates staff to create unique idea depending on human, physical and intellectual resources. Therefore, creativity develops through stages that involve preparation, generation and validation of ideas and assessment of achieved outcome (Stojcic, Hashi, \& Orlic, 2018). Flevy Lasrado (2019), discussed in her book the milestone of innovation in the organization. Where leadership considered the first component that working on creating the next level of leaders, not just followers. Promoting leadership culture is being the role models of innovation, co-creation, foster innovation and enhance communication and sharing information. The second pillar is people as a source of innovation and creativity by encouraging the maximum potential of employees through involving them in decision-making as a clear internal motivation strategy. Capability building considered the third pillar that depending on internal capability investment by aligning several interrelated organization elements and asset. Last pillar depending on developing a model of innovation outcomes that working on five dimensions, which are probability, employee experience, product quality, process improvement of customer experience and innovation portfolio.

Fostering innovation and creativity in the organization has numerous benefits and positive consequences on employee's psychology, behavior and performance, through influence the competitive performance of the firms and affects positively on financial performance (Nguyen \& Le, 2019). Another benefit of innovation and creativity appears in offering sustainability for the organization by enhancing internal capability depending on employee performance, organization structure and learning strategies (Chaubey \& Sahoo, 2019). Alzghoul, Elrehail, Emeagwali, \& AlShboul (2018) urge that workplace climate that emerging creativity and innovation have a positive impact on employees through enhancing job satisfaction, job commitment and job performance. Furthermore, Ismail, Iqbal, \& Nasr(2019) also explained that Organizations can outperform their competitors by providing a creative environment to their employees and opportunities to think and act differently.

\subsection{Organization Culture and Employee Performance}

The literature explains the importance of organization culture on overall organization's performance through referring to Hofstede theory (1965) as a reference point to explain four dimensions of culture which are power distance, uncertainty avoidance, individualism and collectivism and masculinity and femininity (Mahadevan, 2017). But in this part, we will highlight the relationship between employee performance and organization, furthermore, factors that working in enforcing positive culture within employees.

There are numerous definitions of organizational culture. Nikpour (2017) defined organizational culture as the pattern of beliefs, values, and experiences that is reflecting on material arrangements and members behavior. Where Shahzad, Xiu, \& Shahbaz (2017) referred organizational culture to an employee's values, and beliefs shared at all levels and displayed of organizational traits. Warrick (2017) also support those definitions by adding an environment in which organizational member's influence on how members think, act, and gain experience work.

Researchers widely category organization's culture into three types, innovative organizational culture (IOC), bureaucratic organizational culture (BOC) and trust and supportive organizational culture (TOC) (Wu, Huang, 
Huang, \& Du, 2019). An innovative culture is represented by a work environment that is creative, results-oriented, and challenging. This dimension involves an enterprising and opportunity-seeking environment that attracts employees seeking challenge and risk. Bureaucratic culture refers to an organized, systematic, procedural, and regulated work environment. Organizations high on this dimension lack flexibility and emphasize efficiency, predictability, and consistency. A supportive culture is manifested in a work environment that is trusting, peopleoriented, and encouraging. Such culture facilitates open relationships among employees and provides a workplace with equitable, friendly, and helpful (Jogaratnam, 2017). In this review, we are focusing on the influence of an innovative culture.

To build a creative culture, researchers have been described elements that figure out organizational culture. Teamwork, communication, training and development and reward recognition are the main pattern of organization culture (Ramdhani, Ramdhani, \& Ainisyifa, 2017). While Rich, Rich, \& Hair ( 2018) mentioned innovation, outcome orientation, aggressiveness, stability, attention to detail, respect for people and team orientation as main elements of organizational culture. Also, Wu, Huang, Huang \& Du (2019) agreed with them when he mentioned compliance, leadership, decision making, effectiveness and values as elements of organizational culture. Larentis, Antonello, \& Slongo (2019) expanded in their book to cover shared meanings and symbols, openness to new ideas and perspectives, the role of boundary spanners, past experiences and problems' sharing between individuals.

Most scholars agreed in describing organization culture as a magic stick "recipe" that has a positive influence on organization attitude and business improvement process (Mahadevan, 2017). This positiveness expands to reach not only employees and organization performance but also organizational commitment (Nikpour, 2017). Shahzad, Xiu, \& Shahbaz (2017) argue that organizational culture is highly significant, plays a vital role in organizational success and is highly correlated with an employee's satisfaction and performance. Warrick (2017) expand the influence of innovative culture to reach performance, morale, job satisfaction, employee engagement and loyalty, employee attitudes and motivation and tool to attract and retain talented employees.

The correlation between organization culture, knowledge management, information and communication, employee's empowerment and innovation and technology from one side and their impact on employee's performance from other side are clear. Iqbal, Latif, Marimon, Sahibzada, \& Hussain (2019) approve how the correlation between knowledge management and organization culture facilitate organizations task and achieve superior performance. While Al-Abdullat \& Dababneh (2018) conclude that organization successes on applying job satisfaction depending on the combination of clan and adhocracy types of organizational culture and knowledge management through maintaining knowledge sharing environment and empowerment employee's innovative solutions. The four processes of knowledge management framework including sharing (S ), learning (L), evaluation (E), and production (P ) with the combination of well organization culture fit can achieve maximal payoff of employee performance (Zhang, 2018). The organization that building their strategy on adopting correlation between ICT and innovation and creativity has a major influence on employee's performance. This assumption supported by several researchers starting from Ndou, Schiuma \& Passiante (2019) by arguing that creative economy progress measured in terms of human capital performance against implementing clear strategies that maintain information communication technology and innovation and creativity. The same result appeared with Laar, Deursen, Dijk \& Haan (2019) when identified that creativity, communication, collaboration, and analytical skills were presented as skills that are useful to the creative professional.

\section{Conclusion and Limitation}

A broad literature explained employee's performance and the factors influencing this performance. Therefore, this conceptual study contributes to enhancing understanding of factors impacting on employee performance.

As shown in this research, several factors are affecting employee performance. First, organizational knowledge management which has a significant role in improving employee performance through analyzing the current skills, knowledge and ability of employees then design a proper strategy to reduce the gap between the current and desired performance. Second, ICT which are considering the core assets of the organization that are working in encouraging employees to improve their performance. The third factor is the empowerment, which has a tremendous impact on an employee's performance to reshape the attitude of organization in dealing with numerous challenges and threaten in the market, especially if the organization is looking for their employees as a competitive advantage for surviving. Fourth, creative and innovative which are playing as a change-agent in promoting the manifestation of a new idea, which lead the organization to face uncertainty and complexity in a highly changing environment. The fifth factor is an organizational culture, which is working as an umbrella that drives employees performance to develop creative solutions, thinking innovatively and using flexible reasoning in challenging organizational situations (Ismail, Iqbal, \& Nasr, 2019). 
On other hand, the correlation between organization culture, knowledge management, information and communication, employee's empowerment and innovation and technology from one side and employee's performance from other side was clear while analyzing this literature. Where ERP is a functional arm that facilitates the process of collaboration between these factors by empowering employees through aspects of involving in managements concerns, strategic goals and targets, self-learning and developing and knowledge management (Rouhani \& Mehri, 2018).

\section{Research Limitation}

The main limitations of this piece of research are the fact of being conducted only in one database within a limited period, between 2015 and 2019, which influence the accuracy of information. Future research should increase the sample size to collect more data regarding the factors affecting an employee's performance.

\section{References}

Aalmajali, D. A., \& Al-lozi, M. (2019). Reviewing the Literature of The Associations among Knowledge Management, Knowledge Management Infrastructure and Job Satisfaction. Journal of Business \& Management, 7, 1-15. https://doi.org/10.25255/jss.2019.7.1.1.15

Abualoush, S. H., Masa'deh, R., Bataineh, K., \& Alrowwad, A. (2018). The role of knowledge management process and intellectual capital as intermediary variables between knowledge management infrastructure and organization performance. Interdisciplinary Journal of Information, Knowledge, and Management, 13, 279309. https://doi.org/10.28945/4088

Ahbabi, S. A., Singh, S. K., Balasubramanian, S., \& Gaur, S. S. (2019). Employee perception of impact of knowledge management processes on public sector performance. Journal of Knowledge Management, 23, 351-373. https://doi.org/10.1108/JKM-08-2017-0348

Al-Ababneh, M., Al-Sabi, S., Al-Shakhsheer, F., \& Masadeh, M. (2017). The Influence of Employee Empowerment on Employee Job Satisfaction in Five-Star Hotels in Jordan. International Business Research, 10(3), 133-147. https://doi.org/10.5539/ibr.v10n3p133

Al-Abdullat, B. M., \& Dababneh, A. (2018). The mediating effect of job satisfaction on the relationship between organizational culture and knowledge management in Jordanian banking sector. Benchmarking: An International Journal, 25(2), 517-544. https://doi.org/10.1108/BIJ-06-2016-0081

Alazzaz, F., \& Whyte, A. (2015). Linking employee empowerment with productivity in off-site construction. Engineering, Construction and Architectural Management, 22(1), 21-37. https://doi.org/10.1108/ECAM-092013-0083

Aldaihani, S. G. (2019). Administrative empowerment among Kuwait University staff and its effect on their job satisfaction. Journal of Applied Research in Higher Education, 1-20. https://doi.org/10.1108/JARHE-022019-0027

Ali, A. A., Selvam, D. D., Paris, L., \& Gunasekaran, A. (2019). Key factors influencing knowledge sharing practices and its relationship with organizational performance within the oil and gas industry. Journal of Knowledge Management, 1-32.

Alzghoul, A., Elrehail, H., Emeagwali, O. L., \& AlShboul, M. K. (2018). Knowledge management, workplace climate, creativity and performance: The role of authentic leadership. Journal of Workplace Learning, 30(8), 592-612. https://doi.org/10.1108/JWL-12-2017-0111

Ardolino, M., Rapaccini, M., Saccani, N., Gaiardelli, P., Crespi, G., \& Ruggeri, C. (2018). The role of digital technologies for the service transformation of industrial companies. International Journal of Production Research, 56(6), 2116-2132. https://doi.org/10.1080/00207543.2017.1324224

Armstrong, M. (2016). handbook of strategic human resource management. london: Kogan Page.

Asiaei, K., \& Bontis, N. (2019). Translating knowledge management into performance: the role of performance measurement systems. Management Research Review, 33, 1-20. https://doi.org/10.1108/MRR-10-2018-0395

Ax, C., \& Greve, J. (2017). Adoption of management accounting innovations: Organizational culture compatibility and perceived outcomes. Management Accounting Research, 34, 59-74. https://doi.org/10.1016/j.mar.2016.07.007

Ayesha, I., \& Yadav, R. S. (2019). Human resource information systems: a strategic contribution to HRM. Strategic Direction, 35(10), 4-6. https://doi.org/10.1108/SD-02-2019-0043 
Baird, K., Su, S., \& Munir, R. (2018). The relationship between the enabling use of controls, employee empowerment, and performance. Rahat Munir, 47(1), 257-274. https://doi.org/10.1108/PR-12-2016-0324

Bataineh, K. A. (2017). The Impact of Electronic Management on the Employees' Performance. Journal of Management and Strategy, 8(5), 86-100. https://doi.org/10.5430/jms.v8n5p86

Batarlienė, N., Čižiūnienė, K., Vaičiūtè, K., Šapalaite, I., \& Jarašūnienė, A. (2017). The Impact of Human Resource Management on the Competitiveness of Transport Companies. Procedia Engineering, 87, 110-116. https://doi.org/10.1016/j.proeng.2017.04.356

Caputo, F., Cillo, V., Candelo, E., \& Liu, Y. (2019). Innovating through digital revolution: The role of soft skills and Big Data in increasing firm performance. Management Decision, 57(8), 2032-2051. https://doi.org/10.1108/MD-07-2018-0833

Cardy, R. L., \& Miller, J. S. (2005). eHR and Performance Management. THE PROFESSIONAL PRACTICE SERIES. San Francisco: Calif : Jossey-Bass.

Chaubey, A., \& Sahoo, C. K. (2019). Enhancing organizational innovation in Indian automobile industry. International Journal of Innovation Science, 11(1), 82-101. https://doi.org/10.1108/IJIS-02-2018-0022

Cooper, D. J., \& Ezzamel, M. (2013). Globalization discourses and performance measurementsystems in a multinational firm. Accounting, Organizations and Society, 38, 288-313. https://doi.org/10.1016/j.aos.2013.04.002

Dahiya, D., \& Mathew, S. K. (2018). IT infrastructure capability and eGovernment system performance: an empirical study. Transforming Government: People, Process and Policy, 12, 16-38. https://doi.org/10.1108/TG-07-2017-0038

de Menezes, L. M., \& Escrig, A. B. (2019). Managing performance in quality management A two-level study of employee perceptions and workplace performance. International Journal of Operations \& Production Management, 39(11), 1226-1259. https://doi.org/10.1108/IJOPM-03-2019-0207

Ebrahimi, P., Shafiee, B., Gholampour, A., \& Yousefi, L. (2018). Impact of Organizational Innovation, Learning Orientation and Entrepreneurship on SME Performance: The Moderating Role of Market Turbulence and ICT. In D. Khajeheian, M. Friedrichsen, \& W. Modinger, Competitiveness in Emerging Markets (pp. 447-480). 0: Springer, Cham. https://doi.org/10.1007/978-3-319-71722-7_23

Flevy Lasrado. (2019). Fostering Creativity and Innovation. Dubai, United Arab Emirates: Palgrave Macmillan, Cham. Retrieved from https://doi.org/10.1007/978-3-319-99121-4

García-Juan, B., Escrig-Tena, A. B., \& Roca-Puig, V. (2019). The empowerment-organizational performance link in local governments. Personnel Review, 48(1), 118-140. https://doi.org/10.1108/PR-09-2017-0273

Giotopoulos, I., Kontolaimou, A., Korra, E., \& Tsakanikas, A. (2017). What drives ICT adoption by SMEs? Evidence from a large-scale survey in Greece. Journal of Business Research, 81, 60-69. https://doi.org/10.1016/j.jbusres.2017.08.007

Glaister, A. J., Karacay, G., Demirbag, M., \& Tatoglu, E. (2018). HRM and performance - The role of talent management as a transmission mechanism in an emerging market context. Human Resource Management Journal, 148-166. https://doi.org/10.1111/1748-8583.12170

Gunjal, B. (2019). Knowledge Management: Why Do We Need it for Corporates. Malaysian Journal of Library \& Information Science, 10, 37-50. https://doi.org/10.31229/osf.io/fy984

Hughes, D. J., Lee, A., Tian, A. W., Newman, A., \& Legood, A. (2018). Leadership, creativity, and innovation: A critical review and practical recommendations. The Leadership Quarterly, 29, 549-569. https://doi.org/10.1016/j.leaqua.2018.03.001

Hwang, Y., Lin, H., \& Shin, D. (2018). Knowledge system commitment and knowledge sharing intention: The role of personal information management motivation. International Journal of Information Management, 39, 220 227. https://doi.org/10.1016/j.ijinfomgt.2017.12.009

Imran, M. K., Ilyas, M., Aslam, U., \& Fatima, T. (2018). Knowledge processes and firm performance: the mediating effect of employee creativity. Journal of Organizational Change Management, 31, 512-553. https://doi.org/10.1108/JOCM-10-2016-0202

Iqbal, A., Latif, F., Marimon, F., Sahibzada, U. F., \& Hussain, S. (2019). From knowledge management to organizational performance Modelling the mediating role of innovation and intellectual capital in higher 
education. Journal of Enterprise Information Management, 32(1), 36-59. https://doi.org/10.1108/JEIM-042018-0083

Isaac, O., Abdullah, Z., Ramayah, T., \& Mutahar, A. M. (2017). Internet usage, user satisfaction,task-technology fit, and performance impact among public sector employees in Yemen. The International Journal of Information and Learning Technology, 34, 210-241. https://doi.org/10.1108/IJILT-11-2016-0051

Islami, Mulolli, \& Mustafa (2018). Using Management by Objectives as a performance appraisal tool for employee satisfaction. Future Business Journal, 4(1), 94-108. https://doi.org/10.1016/j.fbj.2018.01.001

Ismail, H. N., Iqbal, A., \& Nasr, L. (2019). Employee engagement and job performance in Lebanon: the mediating role of creativity. International Journal of Productivity and Performance Management, 68(3), 506-523. https://doi.org/10.1108/IJPPM-02-2018-0052

Anitha, J. (2013). Determinants of employee engagement and their impact on employee performance. GRG School of Management Studies, 63, 1741-0401.

Jogaratnam, G. (2017). How organizational culture influences market orientation and business performance in the restaurant industry. Journal of Hospitality and Tourism Management, 31, 211-219. https://doi.org/10.1016/j.jhtm.2017.03.002

Jyoti, J., \& Rani, A. (2017). High performance work system and organisational performance: role of knowledge management. Personnel Review, Emerald Publishing Limited, 46, 1770-1795. https://doi.org/10.1108/PR-102015-0262

Khalili, A. (2018). Creativity and innovation through LMX and personal initiative. Journal of Organizational Change Management, 31(2), 323-333. https://doi.org/10.1108/JOCM-09-2016-0183

Kim, T., \& Chang, J. (2019). Organizational culture and performance: a macro-level longitudinal study. Leadership \& Organization Development Journal, 40(1), 65-84. https://doi.org/10.1108/LODJ-08-2018-0291

Kitchenham, B. A., \& Charters, S. (2007). Guidelines for performing Systematic Literature Reviews in Software Engineering. UK: Keele University and University of Durham.

Kõiv, K., Liik, K., \& Heidmets, M. (2019). School leadership, teacher's psychological empowerment and workrelated outcomes. International Journal of Educational Management, 33(7), 1501-1514. https://doi.org/10.1108/IJEM-08-2018-0232

Kraśnicka, T., Głód, W., \& Wronka-Pośpiech, M. (2018). Management innovation, pro-innovation organisational culture and enterprise performance: testing the mediation effect. Review of Managerial Science, 12(3), 737 769. https://doi.org/10.1007/s11846-017-0229-0

Kremer, H., Villamor, I., \& Aguinis, H. (2019). Innovation leadership: Best-practice recommendations for promoting employee creativity, voice, and knowledge sharing. Business Horizons, 62(1), 65-74. https://doi.org/10.1016/j.bushor.2018.08.010

Kundu, S. C., Kumar, S., \& Gahlawat, N. (2019). Empowering leadership and job performance: mediating role of psychological empowerment. Management Research Review, 42(5), 605-624. https://doi.org/10.1108/MRR04-2018-0183

Laar, E. v., Deursen, A. J., Dijk, J. A., \& Haan, J. d. (2019). Twenty-first century digital skills for the creative industries workforce: Perspectives from industry experts. First Monday, 24(1), 1-7.

Larentis, F., Antonello, C. S., \& Slongo, L. A. (2019). Development of Inter-organizational Culture: The Elements. In F. Larentis, C. S. Antonello, \& L. A. Slongo, Inter-Organizational Culture (pp. 27-46). Palgrave Pivot, Cham. https://doi.org/10.1007/978-3-030-00392-0_3

Lewis, R. L., Brown, D. A., \& Sutton, N. C. (2019). Control and empowerment as an organising paradox: implications for management control systems. Accounting, Auditing \& Accountability Journal, 32(2), 483507. https://doi.org/10.1108/AAAJ-11-2017-3223

Mahadevan, K. (2017). Culture driven regeneration (CDR): a conceptual business improvement tool. The TQM Journal, 29(2), 403-420. https://doi.org/10.1108/TQM-05-2015-0061

Melián-González, S., \& Bulchand-Gidumal, J. (2017). Information technology and front office employees' performance. International Journal of Contemporary Hospitality Management, 29, 2159-2177. https://doi.org/10.1108/IJCHM-10-2015-0585

Mensah, J. K. (2018). Talent Management and Employee Outcomes: A Psychological Contract Fulfilment 
Perspective. Springer Science+Business Media, 19, 325-344. https://doi.org/10.1007/s11115-018-0407-9

Nayak, T., Sahoo, C. K., \& Mohanty, P. K. (2018). Workplace empowerment, quality of work life and employee commitment: a study on Indian healthcare sector. Journal of Asia Business Studies, 12(2), 117-136. https://doi.org/10.1108/JABS-03-2016-0045

Ndou, V., Schiuma, G., \& Passiante, G. (2019). Towards a framework for measuring creative economy: evidence from Balkan countries. Measuring Business Excellence, 23(1), 41-62. https://doi.org/10.1108/MBE-03-20180013

Nesan, L. J., \& Holt, G. D. (2002). Assessment of organisational involvement in implementing empowerment. Integrated Manufacturing Systems, 201-211. https://doi.org/10.1108/09576060210426903

Nguyen, T. H., \& Le, A. N. H. (2019). Promoting creativity and innovation: expected and unexpected consequences. Asia Pacific Journal of Innovation and Entrepreneurship, 1-15. https://doi.org/10.1108/APJIE-03-2019-0008

Nikpour, A. (2017). The Impact of Organizational Culture on Organizational Performance: The Mediating Role of Employee's Organizational Commitment. International Journal of Organizational Leadership, 6(3), 65-72. https://doi.org/10.33844/ijol.2017.60432

Obeidat, S. M. (2016). The link between e-HRM use and HRM effectiveness: an empirical study. Personnel Review, 45(6), 1281-1301. https://doi.org/10.1108/PR-04-2015-0111

Olsson, A., Paredes, K. M., Johansson, U., Roese, M. O., \& Ritzén, S. (2019). Organizational climate for innovation and creativity - a study in Swedish retail organizations. The International Review of Retail, Distribution and Consumer Research, 3, 243-261. https://doi.org/10.1080/09593969.2019.1598470

Pawirosumarto, S., Sarjana, P. K., \& Gunawan, R. (2017). The effect of work environment,leadership style, and organizational culture towards job satisfaction and its implication towards employee performance in Parador Hotels and Resorts, Indonesia. International Journal of Law and, 59(6), 1337-1358. https://doi.org/10.1108/IJLMA-10-2016-0085

Potnuru, R. K., Sahoo, C. K., \& Sharma, R. (2019). Team building, employee empowerment and employee competencies: Moderating role of organizational learning culture. European Journal of Training and Development, 43, 39-60. https://doi.org/10.1108/EJTD-08-2018-0086

Rahman, M., Mordi, C., \& Nwagbara, U. (2018). Factors influencing E-HRM implementation in government organisations: Case studies from Bangladesh. Journal of Enterprise Information Management, 31(2), 247275. https://doi.org/10.1108/JEIM-05-2017-0066

Ramdhani, A., Ramdhani, M. A., \& Ainisyifa, H. (2017). Conceptual Framework of Corporate Culture Influenced on Employees Commitment to Organization. International Business Management, 11(3), 826-830. https://doi.org/10.36478/ibm.2017.826.830

Reichstein, C. (2019). Strategic IT management: How companies can benefit from an increasing IT influence. Journal of Enterprise Information Management, 32(2), 251-273. https://doi.org/10.1108/JEIM-08-2018-0172

Revilla, E., \& Rodríguez-Prado, B. (2018). Bulding ambidexterity through creativity mechanisms: Contextual drivers of innovation success. Research Policy, 47(9), 1611-1625. https://doi.org/10.1016/j.respol.2018.05.009

Rich, L. L., Rich, J., \& Hair, J. (2018). The influence of organizational culture on how we define and pursue goals: The value of regulatory focus. Journal of Organizational Effectiveness: People and Performance, 5(3), 259277. https://doi.org/10.1108/JOEPP-03-2018-0017

Rouhani, S., \& Mehri, M. (2018). Empowering benefits of ERP systems implementation: empirical study of industrial firms. Journal of Systems and Information Technology, 20, 54-72. https://doi.org/10.1108/JSIT-052017-0038

Sales, X. (2019). A proposed methodology for evaluating the quality of performance management systems. Pacific Accounting Review, 1-18. https://doi.org/10.1108/PAR-03-2018-0019

Schuckert, M., Kim, T. T., Paek, S., \& Lee, G. (2018). Motivate to innovate: How authentic and transformational leaders influence employees' psychological capital and service innovation behavior. International Journal of Contemporary Hospitality Management, 30(2), 776-796. https://doi.org/10.1108/IJCHM-05-2016-0282

Shah, N., Irani, Z., \& Sharif, A. M. (2017). Big data in an HR context: Exploring organizational change readiness. Journal of Business Research, 70, 366-378. https://doi.org/10.1016/j.jbusres.2016.08.010 
Shah, T. A., Khattak, M. N., Zolin, R., \& Shah, S. Z. (2019). Psychological empowerment and employee attitudinal outcomes: The pivotal role of psychological capital. Management Research Review, 42(7), 797-817. https://doi.org/10.1108/MRR-05-2018-0194

Shahzad, F., Xiu, G., \& Shahbaz, M. (2017). Organizational culture and innovation performance in Pakistan's software industry. Technology in Society, 51, 66-73. https://doi.org/10.1016/j.techsoc.2017.08.002

Shehata, G. M., \& Montash, M. A. (2019). Driving the internet and e-business technologies to generate a competitive advantage in emerging markets: Evidence from Egypt. Information Technology \& People, 1-36. https://doi.org/10.1108/ITP-10-2017-0360

Smith, M., \& Bititci, U. S. (2017). Interplay between performance measurement and management, employee engagement and performance. International Journal of Operations, 37(9), 1207-1228. https://doi.org/10.1108/IJOPM-06-2015-0313

Song, Z., Gu, Q., \& Wang, B. (2019). Creativity-oriented HRM and organizational creativity in China: A complementary perspective of innovativeness. International Journal of Manpower, 40(5), 834-849. https://doi.org/10.1108/IJM-05-2016-0108

Soto-Acosta, P., Popa, S., \& Palacios-Marqués, D. (2016). Social web knowledge sharing and innovation performance in knowledge-intensive manufacturing SMEs. The Journal of Technology Transfer, 42, 425-440. https://doi.org/10.1007/s10961-016-9498-z

Stojcic, N., Hashi, I., \& Orlic, E. (2018). Creativity, innovation effectiveness and productive efficiency in the UK. European Journal of Innovation Management, 21(4), 564-580. https://doi.org/10.1108/EJIM-11-2017-0166

Susanty, A. I., Yuningsih, Y., \& Anggadwita, G. (2019). Knowledge management practices and innovation performance: A study at Indonesian Government apparatus research and training cente. Journal of Science and Technology Policy Management, 10, 301-318. https://doi.org/10.1108/JSTPM-03-2018-0030

Tabatabaei, S. A., Omran, E. S., Hashemi, S., \& Sedaghat, M. (2017). Presenting Sustainable HRM Model Based on Balanced Scorecard in Knowledge-based ICT Companies. Economics and Sociology, 10(2), 107-124. https://doi.org/10.14254/2071-789X.2017/10-2/8

Turulja, L., \& Bajgoric, N. (2018). Information technology, knowledge management and human resource management: Investigating mutual interactions towards better organizational performance. VINE Journal of Information and Knowledge Management Systems, 48(2), 255-276. https://doi.org/10.1108/VJIKMS-062017-0035

Wang, J., Cheng, G. H. L., Chen, T., \& Leung, K. (2019). Team creativity/innovation in culturally diverse teams: A meta-analysis. Journal of Organizational Behavior, 40(6), 693-708. https://doi.org/10.1002/job.2362

Warrick, D. (2017). What leaders need to know about organizational culture. Business Horizons, 60(3), 395-404. https://doi.org/10.1016/j.bushor.2017.01.011

Wu, L. F., Huang, I. C., Huang, W. C., \& Du, P. L. (2019). Aligning organizational culture and operations strategy to improve innovation outcomes: An integrated perspective in organizational management. Journal of Organizational Change Management, 323(2), 224-250. https://doi.org/10.1108/JOCM-03-2018-0073

Zaitouni, M., \& Ouakouak, M. L. (2018). Key predictors of individual creativity in a Middle Eastern culture: The case of service organizations. International Journal of Organizational Analysis, 26(1), 19-42. https://doi.org/10.1108/IJOA-03-2017-1139

Zhang, Z. (2018). Organizational culture and knowledge sharing: design of incentives and business processes. Business Process Management Journal, 24(2), 384-399. https://doi.org/10.1108/BPMJ-08-2015-0119

\section{Copyrights}

Copyright for this article is retained by the author(s), with first publication rights granted to the journal.

This is an open-access article distributed under the terms and conditions of the Creative Commons Attribution license (http://creativecommons.org/licenses/by/4.0/). 